\title{
KOLABORASI PROBLEM \\ BASED LEARNING DAN GROUP \\ INVESTIGATION UNTUK \\ MENINGKATKAN AKTIFITAS DAN \\ HASIL BELAJAR PENDIDIKAN AGAMA \\ ISLAM
}

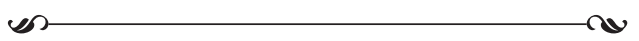

Akhmad Baktiyar Zamzami

SDN Sukabumi 4, Mayangan, Probolinggo Jawa Timur, Indonesia

oum

\begin{abstract}
COLLABORATION OF PROBLEM BASED LEARNING AND GROUP INVESTIGATION TO IMPROVE THE LEARNING ACTIVITY AND RESULT OF ISLAMIC EDUCATION: The subjects of this Clasroom Action Reserach were students of class VI SDN Sukabumi 4 Kota Probolinggo in East Java in the academic year 2015/2016 amounted to 36 people. The purpose of this research are: 1) To find out more about the application of collaboration Problem Based Learning and Group Investigation in improving student learning activities and outcomes of sixth grade Sukabumi SDN 4 Kota Probolinggo; 2) To determine the effect of collaboration Problem Based Learning and Group Investigation to increase activity and student learning outcomes. The result of research collaboration and Problem Based Learning Group Investigation can improve the quality of learning in Islamic Education Material. The positive impact in improving activity and student learning outcomes in the classroom is characterized by increased mastery learning students in each cycle, in the first cycle reached $47.2 \%$ in cycle II reached $86.1 \%$.
\end{abstract}

Key words: problem based learning learning model, group investigation, activities and study result of islamic education

\section{A. Pendahuluan}

Pendidikan merupakan suatu cara untuk membenahi dan meningkatkan kemampuan berfikir seseorang dan kualitas setiap individu baik secara langsung maupun tidak langsung. Perkembangan dan perubahan pendidikan yang semakin maju menuntut lembaga pendidikan atau sekolah 


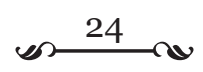

untuk mempersiapkan sumber daya manusia yang lebih baik lagi, dimana tenaga pengajar atau guru dituntut untuk mengembangkan kemampuan dirinya dengan pengetahuan dan keterampilan.

Pembelajaran yang baik selalu mengupayakan proses interaksi belajar mengajar yang bermakna bagi siswa. Itulah sebabnya di dalam belajar, guru merupakan salah satu unsur di dalam proses belajar mengajar yang mempunyai peranan yang penting dan dianggap bertanggung jawab dalam keberhasilan proses pembelajaran. Pada dasarnya setiap guru menginginkan agar semua kompetensi yang terdapat dalam suatu bidang studi dapat tercapai pada setiap proses pembelajaran. Untuk itu, guru harus mampu mengolah kelas dengan baik serta memilih dan menerapkan model pembelajaran yang tepat dalam menyampaikan materi sehingga siswa dapat mengikuti pelajaran dengan baik dan hasil belajarnya semakin maksimal.

Oleh sebab itu, dalam meningkatkan kualitas pembelajaran salah satu upaya yang dilakukan adalah dengan melakukan inovasi pembelajaran, yaitu dengan menciptakan suatu proses belajar mengajar yang lebih menarik, menggembirakan, dan mudah dipahami. Guru dapat memilih berbagai alternatif dalam usaha perbaikan pembelajaran. Salah satu alternatif yang dapat dipilih oleh guru adalah dengan memanfaatkan model pembelajaran koperatif yang dapat disesuaikan dengan situasi dan kondisi siswa. Seorang guru sebaiknya mampu memilih model pembelajaran yang tepat bagi peserta didiknya.

Menurut (Sardiman, 2010: 15) terjadinya interaksi belajar mengajar mempunyai beberapa ciri-ciri antara lain: 1) interaksi belajar mengajar memiliki tujuan dengan menempatkan siswa sebagai pusat perhatian; 2) ditandai dengan adanya aktifitas siswa. Aktifitas siswa dalam hal ini merupakan syarat mutlak baik secara mental aktif; 3) dalam interaksi belajar mengajar guru berusaha menghidupkan, memberi motivasi, mediator dalam proses interaksi belajar mengajar.

Pembelajaran Pendidikan Agama Islam dimaksudkan dalam (Mulyono, 2007: 14) untuk meningkatkan potensi moral dan spiritual yang mencakup pengenalan, pemahaman, penanaman, dan pengamalan nilainilai keagamaan dalam kehidupan individual maupun kolektif masyarakat.

Dalam kenyataannya, pembelajaran mata pelajaran Pendidikan Agama Islam, khususnya di SDN Sukabumi 4 Kota Probolinggo Jawa Timur, dalam pelaksanaannya masih menunjukkan berbagai permasalahan yang kurang 


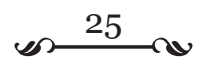

menyenangkan, seperti halnya proses pembelajaran Pendidikan Agama Islam lebih memperhatikan aspek kognitif semata daripada pertumbuhan kesadaran nilai-nilai (agama) dan mengabaikan pembinaan aspek afektif dan konatif volutif, yakni kemauan tekad untuk mengamalkan nilai-nilai ajaran agama. Dengan kata lain, Pendidikan Agama Islam lebih berorientasi pada belajar bagaimana cara beragama yang benar. Akibatnya sebagaimana dalam (Muhaimin, dkk, 2004: 106-107) terjadi kesenjangan antara pengetahuan dan pengamalan, antara gnosis dan praxis dalam kehidupan nilai agama, sehingga tidak mampu membentuk pribadi-pribadi Islami.

Hasil analisis akan menunjukkan kondisi pembelajaran yang bagaimana dan apa hasil pembelajaran Pendidikan Agama Islam yang diharapkan. Setelah mengolaborasikan model pembelajaran problem based learning dan group investigation akan diperoleh informasi yang lengkap mengenai kondisi riil yang ada dan hasil pembelajaran yang diharapkan.

Mengingat permasalahan yang ada di SDN Sukabumi 4 Kota Probolinggo Jawa Timur, maka penulis tertarik untuk melakukan penelitian dengan judul "Kolaborasi Problem Based Learning Dan Group Investigation Untuk Meningkatkan Aktifitas Dan Hasil Belajar Pendidikan Agama Islam Pada Materi Senangnya berakhlak terpuji”. Sehingga akan terlihat:

1. Sejauhmana kolaborasi model pembelajaran problem based learning dan group investigation dapat meningkatkan aktifitas belajar pendidikan agama islam pada materi senangnya berakhlak terpuji?

2. Sejauhmana pula kolaborasi model pembelajaran problem based learning dan group investigation dapat meningkatkan hasil belajar pendidikan agama islam pada materi senangnya berakhlak terpuji?

Penelitian ini dilakukan di SDN Sukabumi 4 Kota Probolinggo, Jalan Soekarno Hatta Nomor 72 Kota Probolinggo Provinsi Jawa Timur. Waktu penelitian ini adalah pada semester genap Tahun Pelajaran 2015/2016, dilaksanakan pada bulan Pebruari sampai Maret 2016, dengan tatap muka (masing-masing alokasi waktu 4 x 35 menit). Adapun subjek penelitian adalah siswa kelas VI SDN Sukabumi 4 Kota Probolinggo yang berjumlah 36 orang.

Metode penelitian yang digunakan dalam penelitian ini adalah Penelitian Tindakan Kelas atau classroom action research model Kurt Lewin yang terdiri dari empat komponen tahapan, yaitu perencanaan (planning), tindakan (acting), pengamatan (observating), dan refleksi 


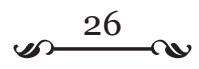

(reflecting). Penelitian ini dilaksanakan dalam 2 siklus, dengan rincian siklus 1 dilaksanakan dengan dua siklus.

Siklus pertama dimulai dengan melakukan pre-test terhadap siswa yang bertujuan untuk mengukur kemampuan awal siswa sebelum materi disampaikan. Kemudian guru membagi siswa ke dalam beberapa kelompok, dan setiap kelompok terdiri dari 6 peserta didik. Guru dan peserta didik bersama menyusun prosedur pembelajaran yang terkait dengan permasalahan yang akan dibahas oleh peserta didik. Kemudian setiap kelompok membahas permasalahan yang diberikan oleh guru. Hasil diskusi dipresentasikan oleh setiap kelompok. Kemudian guru bersama-sama siswa menyimpulkan materi pembelajaran. Hasil siklus pertama dievaluasi dan dibuat refleksinya untuk mengukur tingkat ketercapaian tujuan. Hasil refleksi digunakan untuk merencanakan tahap lanjutan pada siklus kedua.

Siklus kedua dimulai dengan perencanaan yaitu memberikan setiap kelompok permasalahan yang akan dibahas peserta didik. Setiap kelompok menganalisis soal yang telah diberikan oleh guru, memberikan tanggapan dan menemukan penyelesaian soal tersebut. Guru mengawasi jalannya diskusi dan memberikan arahan jika ada kelompok yang kurang mengerti. Setelah selesai mengerjakan soal tersebut, guru menyuruh salah satu anggota dari setiap kelompok untuk mengerjakan hasil diskusi mereka di papan tulis. Di akhir pertemuan diadakan post-test untuk menilai ketercapaian hasil belajar siswa. Pada siklus ini guru lebih banyak memberikan permasalahan yang akan dibahas oleh peserta didik, sehingga pengetahuan mereka semakin berkembang.

Instrumen-instrumen yang digunakan dalam penelitian ini adalah:

a. Instrumen untuk menilai aktifitas siswa menggunakan lembar penilaian aktifitas.

b. Data yang dikumpulkan dalam penelitian ini adalah tes hasil belajar berbentuk essay test.

\section{B. Pembahasan}

\section{Model Pembelajaran Problem Based Learning}

Menurut Arends (Trianto, 2007: 68) menyatakan bahwa:"Model pembelajaran berdasarkan masalah merupakan suatu pendekatan pembelajaran di mana siswa mengerjakan permasalahan yang autentik dengan 


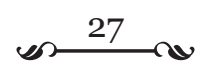

maksud untuk menyusun pengetahuan mereka sendiri, mengembangkan inkuiri dan keterampilan berpikir tingkat lebih tinggi, mengembangkan kemandirian dan percaya diri”. Model pembelajaran berdasarkan masalah juga mengacu pada model pembelajaran yang lain seperti yang diungkapkan oleh diungkapkan oleh (Trianto, 2007: 68) : "Model pembelajaran berdasarkan masalah) mengacu pada Pembelajaran Proyek (Project Based Learning), Pendidikan Berdasarkan Pengalaman (Experience Based Education), Belajar Autentik (Autentic Learning), Pembelajaran Bermakna (Anchored Instruction)".

Berbagai pengembang menyatakan bahwa ciri utama model pembelajaran berdasarkan masalah ini dalam (Trianto, 2007: 68) adalah:

\section{a. Pengajuan pertanyaan atau masalah.}

Guru memunculkan pertanyaan yang nyata di lingkungan siswa serta dapat diselidiki oleh siswa kepada masalah yang autentik ini dapat berupa cerita, penyajian fenomena tertentu, atau mendemontrasikan suatu kejadian yang mengundang munculnya permasalahan atau pertanyaan.

\section{b. Berfokus pada keterkaitan antar disiplin.}

Meskipun pembelajaran berdasarkan masalah mungkin berpusat pada mata pelajaran tertentu masalah yang dipilih benar-benar nyata agar dalam pemecahannya, siswa dapat meninjau dari berbagai mata pelajaran yang lain.

\section{c. Penyelidikan autentik.}

Pembelajaran berdasarkan masalah mengharuskan siswa melakukan penyelidikan autentik untuk mencari penyelesaian nyata terhadap masalah yang disajikan. Metode penyelidikan ini bergantung pada masalah yang sedang dipelajari.

\section{d. Menghasilkan produk atau karya.}

Pembelajaran berdasarkan masalah menuntut siswa untuk menghasilkan produk tertentu dalam bentuk karya dan peragaan yang menjelaskan atau mewakili bentuk penyelesaian masalah yang mereka temukan. Produk itu dapat juga berupa laporan, model fisik, video maupun program komputer

Pada Model pembelajaran berdasarkan masalah sebagaimana (Nurhadi, 2004: 111) terdapat lima tahap utama yang dimulai dengan memperkenalkan siswa tehadap masalah yang diakhiri dengan tahap penyajian dan analisis hasil kerja siswa. Kelima tahapan tersebut disajikan dalam bentuk tabel. 
Tabel 1 Sintaks Model pembelajaran berdasarkan masalah

\begin{tabular}{|c|c|c|}
\hline Fase & Indikator & Aktifitas / Kegiatan Guru \\
\hline 1 & $\begin{array}{l}\text { Orientasi siswa } \\
\text { kepada masalah }\end{array}$ & $\begin{array}{l}\text { Guru menjelaskan tujuan pembelajaran, } \\
\text { menjelaskan logistikyang diperlukan, } \\
\text { pengajuan masalah, memotivasi siswa } \\
\text { terlibat dalam aktifitas pemecahan } \\
\text { masalah yang dipilihnya. }\end{array}$ \\
\hline 2 & $\begin{array}{l}\text { Mengorganisasikan } \\
\text { siswa untuk belajar }\end{array}$ & $\begin{array}{l}\text { Guru membantu siswa mendefenisikan } \\
\text { dan mengorganisasikan tugas belajar yang } \\
\text { berhubungan dengan masalah tersebut. }\end{array}$ \\
\hline 3 & $\begin{array}{l}\text { Membimbing } \\
\text { penyelidikan } \\
\text { individual maupun } \\
\text { kelompok }\end{array}$ & $\begin{array}{l}\text { Guru mendorong siswa untuk } \\
\text { mengumpulkan informasi yang sesuai, } \\
\text { melaksanakan eksperimen, untuk } \\
\text { mendapat penjelasan pemecahan } \\
\text { masalah. }\end{array}$ \\
\hline 4 & $\begin{array}{l}\text { Mengembangkan } \\
\text { dan menyajikan hasil } \\
\text { karya }\end{array}$ & $\begin{array}{l}\text { Guru membantu siswa dalam } \\
\text { merencanakan dan menyiapkan karya } \\
\text { yang sesuai seperti laporan, video, model } \\
\text { dan membantu mereka untuk berbagai } \\
\text { tugas dengan kelompoknya. }\end{array}$ \\
\hline 5 & $\begin{array}{l}\text { Menganalisa dan } \\
\text { mengevaluasi proses } \\
\text { pemecahan masalah }\end{array}$ & $\begin{array}{l}\text { Guru membantu siswa melakukan refleksi } \\
\text { atau evaluasi terhadap penyelidikan } \\
\text { mereka dalam proses-proses yang mereka } \\
\text { gunakan. }\end{array}$ \\
\hline
\end{tabular}

\section{Pengertian Model Pembelajaran Group Investigation}

Height menyatakan to investigation berkaitan dengan kegiatan mengobservasi secara rinci dan menilai secara sistematis. Jadi investigasi adalah proses penyelidikan yang dilakukan seseorang, dan selanjutnya orang tersebut mengkomunikasikan hasil perolehannya, dapat membandingkannya dengan perolehan orang lain, karena dalam suatu investigasi dapat diperoleh satu atau lebih hasil. Dengan demikian, akan dapat dibiasakan untuk lebih mengembangkan rasa ingin tahu. Hal ini akan membuat siswa untuk lebih aktif berpikir dan mencetuskan ide-ide atau gagasan, serta dapat menarik kesimpulan berdasarkan hasil diskusinya di kelas. Model Pembelajaran 


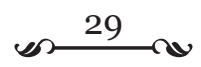

Group Investigation adalah suatu tipe Model Pembelajaran Berbasis (Projectbased Learning).

Group Investigation merupakan salah satu bentuk model pembelajaran kooperatif yang menekankan pada partisipasi dan aktifitas siswa untuk mencari sendiri materi (informasi) pelajaran yang akan dipelajari melalui bahan-bahan yang tersedia, misalnya dari buku pelajaran atau siswa dapat mencari melalui internet. Siswa dilibatkan sejak perencanaan, baik dalam menentukan topik maupun cara untuk mempelajarinya melalui investigasi. Tipe ini menuntut para siswa untuk memiliki kemampuan yang baik dalam berkomunikasi maupun dalam keterampilan proses kelompok. Model Group Investigation dapat melatih siswa untuk menumbuhkan kemampuan berfikir mandiri. Keterlibatan siswa secara aktif dapat terlihat mulai dari tahap pertama sampai tahap akhir pembelajaran.

Pengembangan belajar kooperatif GI didasarkan atas suatu premis bahwa proses belajar di sekolah menyangkut kawasan dalam domain sosial dan intelektual, dan proses yang terjadi merupakan penggabungan nilai-nilai kedua domain tersebut. Oleh karena itu, GI tidak dapat diimplementasikan ke dalam lingkungan pendidikan yang tidak bisa mendukung terjadinya diaolog interpersonal (atau tidak mengacu kepada dimensi sosial-afektif pembelajaran). Aspek sosial-afektif kelompok, pertukaran intelektualnya, dan materi yang bermakna, merupakan sumber primer yang cukup penting dalam memberikan dukungan terhadap usaha-usaha belajar siswa. Interaksi dan komunikasi yang bersifat kooperatif di antara siswa dalam satu kelas dapat dicapai dengan baik, jika pembelajaran dilakukan lewat kelompokkelompok belajar kecil.

Kesuksesan implementasi teknik kooperatif GI menurut (Rusman: 2011, 221) sangat tergantung dari pelatihan awal dalam penguasaan keterampilan komunikasi dan sosial. Tugas-tugas akademik harus diarahkan kepada pemberian kesempatan bagi anggota kelompok untuk memberikan berbagai macam kontribusinya, bukan hanya sekadar didesain untuk mendapat jawaban dari suatu pertanyaan yang bersifat faktual (apa, siapa, di mana, atau sejenisnya).

Model ini menurut (Nana Sudjana: 1991, 50) lebih menekankan pengembangan kemampuan memecahkan permasalahan dalam suasana yang demokratis dimana pengetahuan tidak diajarkan secara langsung kepada siswa, tetapi diperoleh melalui proses pemecahan masalah. 


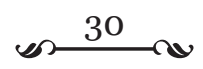

Untuk meningkatkan peluang keberhasilan dalam memecahkan menurut (Udin S. Winaputra: 2001, 75) harus lebih dahulu memahami komponen emosional dan irrasional.

Siti Maesaro dalam (Siti Maesaro: 2005, 28) mengemukakan hal penting untuk melakukan metode Group Investigation adalah:

1. Membutuhkan Kemampuan Kelompok.

Di dalam mengerjakan setiap tugas, setiap anggota kelompok harus mendapat kesempatan memberikan kontribusi. Dalam penyelidikan, siswa dapat mencari informasi dari berbagai informasi dari dalam maupun di luar kelas. Kemudian siswa mengumpulkan informasi yang diberikan dari setiap anggota untuk mengerjakan lembar kerja.

2. Rencana Kooperatif.

Siswa bersama-sama menyelidiki masalah mereka, sumber mana yang mereka butuhkan, siapa yang melakukan apa, dan bagaimana mereka akan mempresentasikan proyek mereka di dalam kelas.

3. Peran Guru.

Guru menyediakan sumber dan fasilitator. Guru memutar di antara kelompok-kelompok memperhatikan siswa mengatur pekerjaan dan membantu siswa mengatur pekerjaannya dan membantu jika siswa menemukan kesulitan dalam interaksi kelompok.

Para guru yang menggunakan metode GI umumnya membagi kelas menjadi beberapa kelompok yang beranggotakan 5 sampai 6 siswa dengan karakteristikyang heterogen. Pembagian kelompok dapat juga didasarkan atas kesenangan berteman atau kesamaan minat terhadap suatu topik tertentu. Selanjutnya siswa memilih topik untuk diselidiki, melakukan penyelidikan yang mendalam atas topik yang telah dipilih, kemudian menyiapkan dan mempresentasikan laporannya di depan kelas.

Tahapan-tahapan kemajuan siswa di dalam pembelajaran yang menggunakan metode Group Investigation untuk lebih jelasnya dapat dilihat pada tabel berikut.

Tabel 2 Sintaks Model Pembelajaran Group Investigation

\begin{tabular}{|c|c|c|}
\hline Fase & Indikator & Aktifitas / Kegiatan Guru \\
\hline $\mathbf{1}$ & $\begin{array}{l}\text { Mengidentifikasi } \\
\text { topik dan membagi }\end{array}$ & $\begin{array}{l}\text { Guru memberikan kesempatan bagi siswa } \\
\text { untuk memberi kontribusi apa yang akan }\end{array}$ \\
\hline
\end{tabular}




\begin{tabular}{|c|c|c|}
\hline & $\begin{array}{l}\text { siswa ke dalam } \\
\text { kelompok. }\end{array}$ & $\begin{array}{l}\text { mereka selidiki. Kelompok dibentuk } \\
\text { berdasarkan heterogenitas. }\end{array}$ \\
\hline 2 & $\begin{array}{l}\text { M e r e n c a n a k a n } \\
\text { tugas. }\end{array}$ & $\begin{array}{l}\text { Kelompok akan membagi sub topik kepada } \\
\text { seluruh anggota. Kemudian membuat } \\
\text { perencanaan dari masalah yang akan } \\
\text { diteliti, bagaimana proses dan sumber apa } \\
\text { yang akan dipakai. }\end{array}$ \\
\hline 3 & $\begin{array}{l}\mathrm{M} \text { e } \mathrm{m} \mathrm{b} \mathrm{u} \text { a } \mathrm{t} \\
\text { penyelidikan. }\end{array}$ & $\begin{array}{l}\text { Siswa mengumpulkan, menganalisis } \\
\text { dan mengevaluasi informasi, membuat } \\
\text { kesimpulan dan mengaplikasikan bagian } \\
\text { mereka ke dalam pengetahuan baru dalam } \\
\text { mencapai solusi masalah kelompok. }\end{array}$ \\
\hline 4 & $\begin{array}{l}\text { Mempersiapkan } \\
\text { tugas akhir. }\end{array}$ & $\begin{array}{l}\text { Setiap kelompok mempersiapkan tugas } \\
\text { akhir yang akan dipresentasikan di depan } \\
\text { kelas. }\end{array}$ \\
\hline 5 & $\begin{array}{l}\text { Mempresentasikan } \\
\text { tugas akhir. }\end{array}$ & $\begin{array}{l}\text { Siswa mempresentasikan hasil kerjanya. } \\
\text { Kelompok lain tetap mengikuti. }\end{array}$ \\
\hline 6 & Evaluasi. & $\begin{array}{l}\text { Soal ulangan mencakup seluruh topik yang } \\
\text { telah diselidiki dan dipresentasikan. }\end{array}$ \\
\hline
\end{tabular}

\section{Kolaborasi Metode Pembelajaran Problem Based Learning dan Group Investigation}

Salah satu model pembelajaran yang dapat digunakan adalah penerapan kolaborasi model pembelajaran Problem Based Learning (PBL) dan Group Investigation (GI). Kolaborasi merupakan kerjasama antara model pembelajaran Problem Based Learning (PBL) dan Group Investigation (GI) yang memberikan kesempatan kepada guru untuk mengelola pembelajaran di kelas dengan melibatkan seluruh siswa agar berperan aktif.

Model Pembelajaran Berbasis Masalah (PBL) merupakan model pembelajaran yang menggunakan masalah sebagai langkah awal dalam mengumpulkan dan mengintegrasikan pengetahuan baru. Siswa diberikan permasalahan pada awal pelaksanaan pembelajaran oleh guru, selanjutnya selama pelaksanaan pembelajaran siswa memecahkan masalah yang pada akhirnya mengintegrasikan pengetahuan dalam bentuk laporan. 


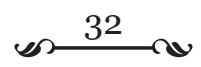

\section{Pengertian Aktifitas Belajar}

Belajar sangat dibutuhkan adanya aktifitas, sebagaimana dalam (Nanang Hanafiah, 2010:23) dikarenakan tanpa adanya aktifitas proses belajar tidak mungkin berlangsung dengan baik. Pada proses aktifitas pembelajaran harus melibatkan seluruh aspek peserta didik, baik jasmani maupun rohani sehingga perubahan perilakunya dapat berubah dengan cepat, tepat, mudah dan benar, baik berkaitan dengan aspek kognitif afektif maupun psikomotor.

Aktifitas belajar adalah aktifitas yang bersifat fisik maupun mental. Dalam proses belajar kedua aktifitas itu harus saling berkaitan. Lebih lanjutlagi piaget menerangkan dalam buku Sardiman bahwa jika seorang anak berfikir tanpa berbuat sesuatu, berarti anak itu tidak berfikir (Sardiman, 2011:100). (Nanang Hanafiah dan Cucu Suhana, 2010: 24) menjelaskan bahwa aktifitas belajar dapat memberikan nilai tambah (added value) bagi peserta didik, berupa hal-hal berikut ini:

1. Peserta didik memiliki kesadaran (awareness) untuk belajar sebagai wujud adanya motivasi internal untuk belajar sejati.

2. Peserta didik mencari pengalaman dan langsung mengalami sendiri, yang dapat memberikan dampak terhadap pembentukan pribadi yang integral.

3. Peserta didik belajar dengan menurut minat dan kemampuannya.

4. Menumbuh kembangkan sikap disiplin dan suasana belajar yang demokratis di kalangan peserta didik.

5. Pembelajaran dilaksanakan secara konkret sehingga dapat menumbuh kembangkan pemahaman dan berfikir kritis serta menghindarkan terjadinya verbalisme.

6. Menumbuh kembangkan sikap kooperatif di kalangan peserta didik sehingga sekolah menjadi hidup, sejalan dan serasi dengan kehidupan di masyarakat di sekitarnya.

Paul B. Diedrich yang dikutip dalam (Nanang hanafiah dan Cucu suhana, 2010:24) menyatakan, aktifitas belajar dibagi ke dalam delapan kelompok, yaitu sebagai berikut:

1. Kegiatan-kegiatan visual (visual activities), yaitu membaca, melihat gambar-gambar, mengamati eksperimen, demonstrasi, pameran dan mengamati orang lain bekerja atau bermain. 


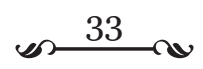

2. Kegiatan-kegiatan lisan (oral activities), yaitu mengemukakan suatu fakta atau prinsip, menghubungkan suatu kejadian mengajukan pertanyaan, memberi saran, mengemukakan pendapat, berwawancara diskusi dan interupsi

3. Kegiatan-kegiatan mendengarkan (listening activities), yaitu mendengarkan penyajian bahan, mendengarkan percakapan atau diskusi kelompok, atau mendengarkan radio.

4. Kegiatan-kegiatan menulis (writing activities), yaitu menulis cerita, menulis laporan, memeriksa karangan, bahan-bahan copy, membuat outline atau rangkuman, dan mengerjakan tes serta mengisi angket.

5. Kegiatan-kegiatan menggambar (drawing activities), yaitu menggambar, membuat grafik, diagram, peta dan pola.

6. Kegiatan-kegiatan motorik (motor activities), yaitu melakukan percobaan, memilih alat-alat, melaksanakan pameran, membuat model, menyelenggarakan permainan, serta menari dan berkebun.

7. Kegiatan-kegiatan mental (mental activities), yaitu merenungkan mengingat, memecahkan masalah, menganalisa faktor-faktor, melihat hubungan-hubungan, dan membuat keputusan.

8. Kegiatan-kegiatan emosional (emotional activities), yaitu minat, membedakan, berani, tenang, merasa bosan dan gugup.

Dengan adanya pembagian jenis aktifitas di atas, menunjukkan bahwa aktifitas di sekolah cukup kompleks dan bervariasi. Jika kegiatankegiatan tersebut dapat tercipta di sekolah, pastilah sekolah-sekolah akan lebih dinamis, tidak membosankan dan benar-benar menjadi pusat aktifitas belajar yang maksimal.

\section{Pengertian Hasil Belajar}

Hasil belajar merupakan tujuan akhir dilaksanakannya kegiatan pembelajaran di sekolah. Hasil belajar sebagaimana dalam (Dimyati dan Mudjiono, 2009: 3) dapat ditingkatkan melalui usaha sadar yang dilakukan secara sistematis mengarah kepada perubahan yang positif yang kemudian disebut dengan proses belajar. Akhir dari proses belajar adalah perolehan suatu hasil belajar siswa. Hasil belajar siswa di kelas terkumpul dalam himpunan hasil belajar kelas. Semua hasil belajar tersebut merupakan hasil dari suatu interaksi tindak belajar dan tindak mengajar. Dari sisi guru, tindak mengajar di akhiri dengan proses evaluasi hasil belajar, sedangkan dari sisi siswa, hasil 


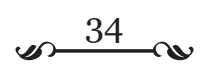

belajar merupakan berakhirnya penggal dan puncak proses belajar.

Menurut (Sudjana, 2010: 22), hasil belajar adalah kemampuan yang dimiliki siswa setelah menerima pengalaman belajar. Selanjutnya Warsito (Depdiknas, 2006: 125) mengemukakan bahwa hasil dari kegiatan belajar ditandai dengan adanya perubahan perilaku ke arah positif yang relatif permanen pada diri orang yang belajar. Sehubungan dengan pendapat itu, maka sesorang dapat dikatakan telah berhasil dalam belajar jika ia mampu menunjukkan adanya perubahan dalam dirinya. Perubahan-perubahan tersebut di antaranya dari segi kemampuan berpikirnya, keterampilannya, atau sikapnya terhadap suatu objek.

Jika dikaji lebih mendalam, maka hasil belajar dapat tertuang dalam taksonomi Bloom, yakni dikelompokkan dalam tiga ranah (domain) yaitu domain kognitif atau kemampuan berpikir, domain afektif atau sikap, dan domain psikomotor atau keterampilan. Sehubungan dengan itu, Gagne (Sudjana, 2010: 22) mengembangkan kemampuan hasil belajar menjadi lima macam antara lain: (1) hasil belajar intelektual merupakan hasil belajar terpenting dari sistem linguiskolastik; (2) strategi kognitif yaitu mengatur cara belajar dan berfikir seseorang dalam arti seluas-luasnya termaksuk kemampuan memecahkan masalah; (3) sikap dan nilai, berhubungan dengan arah intensitas emosional dimiliki seseorang sebagaimana disimpulkan dari kecenderungan bertingkah laku terhadap orang dan kejadian; (4) informasi verbal, pengetahuan dalam arti informasi dan fakta; dan (5) keterampilan motorik yaitu kecakapan yang berfungsi untuk lingkungan hidup serta memprestasikan konsep dan lambang.

Untuk mengetahui hasil belajar seseorang dapat dilakukan dengan melakukan tes dan pengukuran. Tes dan pengukuran memerlukan alat sebagai pengumpul data yang disebut dengan instrumen penilaian hasil belajar. Selanjutnya, menurut (Hamalik, 2006: 155), memberikan gambaran bahwa hasil belajar yang diperoleh dapat diukur melalui kemajuan yang diperoleh siswa setelah belajar dengan sungguh-sungguh. Hasil belajar tampak terjadinya perubahan tingkah laku pada diri siswa yang dapat diamati dan diukur melalui perubahan sikap dan keterampilan. Perubahan tersebut dapat diartikan terjadinya peningkatan dan pengembangan yang lebih baik dibandingkan dengan sebelumnya.

Penelitian Tindakan Kelas ini menerapkan kolaborasi model pembelajaran Problem Based Learning dan Group Investigation untuk 


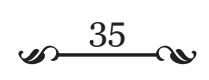

Meningkatkan Aktifitas dan Hasil Belajar PAI materi senangnya berakhlak terpuji siswa kelas VI. Penelitian ini terdiri dari dua siklus di mana setiap siklus dilaksanakan dua kali pertemuan dan pada setiap akhir siklus diberikan post-test untuk mengetahui perubahan yang terjadi. Masing-masing siklus dilakukan pengukuran terhadap aktifitas dan hasil belajar peserta didik. Adapun hasil dari penelitian:

\section{Aktifitas Belajar}

Berdasarkan kriteria penilaian aktifitas, seorang siswa dikatakan aktif belajar jika skor aktifitas yang diperolehnya sebesar $\geq 23$. Kelas dinyatakan telah aktif apabila persentase keaktifan kelas mencapai $75 \%$. Persentase aktifitas belajar secara klasikal pada siklus I belum mencapai ketuntasan klasikal untuk aktifitas belajar karena hanya mencapai 47,2\%, sedangkan kelas dinyatakan telah aktif jika 75\% dari jumlah siswa telah aktif (Skor Penilaian Aktifitasnya minimal 23).

Berdasarkan hasil observasi siklus II, diketahui bahwa keaktifan kelas tersebut mencapai 86,1\%. Oleh karena itu, ketuntasan klasikal untuk aktifitas telah terpenuhi. Peningkatan sebesar 38,9\% dari siklus I ke siklus II

\section{Hasil Belajar}

Untuk hasil belajar siswa, pada siklus I diperoleh sebesar 47,2\% atau 17 siswa yang mencapai KKM yang berarti belum mencapai indikator keberhasilan yaitu 75\% sehingga penelitian berlanjut ke siklus II.

Oleh sebab itu, perlu dilakukan siklus II. Pada siklus II terdapat peningkatan yang cukup signifikan yaitu hasil belajar yang diperoleh menjadi sebesar 86,1\% atau 31 siswa yang mencapai KKM yang berarti telah melampaui indikator keberhasilan yaitu $75 \%$, jadi peningkatan dari siklus I ke siklus II sebesar 38,9\%.

\section{Perbedaan Peningkatan Hasil Belajar Antar Siklus}

Ada perbedaan yang signifikan antara siklus I dan siklus II, hal ini dapat terlihat dari uji - t yang dilakukan. Di mana dari hasil perhitungan diperoleh $t_{\text {(hitung) }}=13,07$ dan $t_{\text {(tabel) }}=2,028$. Dengan membandingkan $t_{\text {(hitung) }}$ dan $t_{\text {(tabel) }}$ diperoleh $t_{\text {(hitung) }}>t_{\text {(tabel) }}$ yaitu 13,07 $>$ 2,028 sehingga perbandingan belajar PAI materi Senangnya berakhlak terpuji siswa kelas VI SDN Sukabumi 4 Kota Probolinggo tahun pelajaran 2015/2016 pada post-test siklus I dengan post-test siklus II adalah signifikan dan positif dengan kata lain hipotesis 3 diterima 


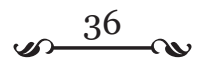

\section{Simpulan}

Berdasarkan hasil penelitian dan pembahasan maka dapat disimpulkan yaitu Penerapan kolaborasi model pembelajaran Problem Based Learning dan Group Investigation dapat meningkatkan aktifitas belajar siswa Hal ini terlihat dari tingkat kerja sama dan keaktifan siswa yang mengalami peningkatan. Dimana aktifitas siswa pada siklus I hanya rata-rata 47,2\% yang berarti belum mencapai indikator keberhasilan senilai $75 \%$ sehingga penelitian dilanjutkan ke siklus II menjadi $86,1 \%$ pada siklus II yang berarti telah melampaui indikator keberhasilan $75 \%$. Peningkatan sebesar 38,9\% dari siklus I ke siklus II.

Penerapan kolaborasi model pembelajaran Problem Based Learning dan Group Investigation dapat meningkatkan hasil belajar PAI materi senangnya berakhlak terpuji siswa. Hal ini dapat dilihat pada siklus I hasil belajar yang diperoleh sebesar 47,2\% atau 17 siswa yang mencapai KKM yang berarti belum mencapai indikator keberhasilan yaitu $75 \%$ sehingga penelitian berlanjut ke siklus II. Kemudian pada siklus II terdapat peningkatan yang cukup signifikan yaitu hasil belajar yang diperoleh menjadi sebesar $86,1 \%$ atau 31 siswa yang mencapai KKM yang berarti telah melampaui indikator keberhasilan yaitu $75 \%$, jadi peningkatan dari siklus I ke siklus II sebesar $38,9 \%$.

Ada perbedaan hasil belajar yang signifikan antara siklus I dan siklus II, hal ini dapat terlihat dari uji-t yang dilakukan. Dimana dari hasil perhitungan uji t diperoleh $\mathrm{t}_{\text {(hitung) }}=13,07$ dan $\mathrm{t}_{\text {(tabel) }}=2,028$. Dengan membandingkan $\mathrm{t}_{\text {(hitung) }}$ dan $\mathrm{t}_{\text {(tabel) }}$ diperoleh $\mathrm{t}_{\text {(hitung) }}>\mathrm{t}_{\text {(tabel) }}$ yaitu 13,07 $>$ 2,028 sehingga ada perbedaan peningkatan hasil belajar PAI materi senangnya berakhlak terpuji siswa kelas VI SDN Sukabumi 4 Kota Probolinggo. 


\section{。然。 \\ DAFTAR PUSTAKA}

A.M. Sardiman. 2011. Interaksi dan Motivasi Belajar Mengajar. Jakarta: Rajawali.

Diedrich. 2011. dalam Sardiman, Interaksi dan Motivasi Belajar Mengajar, Jakarta: PT. Rajagrafindo Persada.

Depdiknas. 2006. Bunga Rampai Keberhasilan Guru dalam Pembelajaran (SMA, SMK, dan SLB). Jakarta: Depdiknas.

Dimyati dan Mudjiono. 2009. Belajar dan Pembelajaran. Jakarta: PT Rineka Cipta.

Hamalik, Oemar. 2006. Proses Belajar Mengajar. Jakarta: PT Bumi Aksara Hanafiah, Nanang \& Cucu Suhana. 2010. Konsep Strategi Pembelajaran. Bandung: Refika Aditama.

Maesaroh, Siti. 2005. Efektivitas Penerapan Pembelajaran Kooperatif Dengan Metode Group Investigation Terhadap Hasil Belajar Matematika Siswa, Jakarta: Universitas Islam Negeri Syarif Hidayatullah

Sadirman, A. M. 2010. Interaksi dan Motivasi Belajar Mengajar, Jakarta:

PT. Raja Grafindo Persada

Sanjaya, Wina. 2011. Strategi Pembelajaran Berorientasi Standart Proses Pendidikan, Jakarta: Kencana.

Trianto. 2009. Mendesain Model Pembelajaran Inovatif-Progresif. Jakarta: Kencana Persada Media Group.

Sudjana, Nana dan Suwariyah, Wari. 1991. Model-model Mengajar CBSA, Bandung: CV Sinar Baru

Sudjana. Nana. 2010. Dasar-Dasar Proses Belajar Mengajar. Bandung: Sinar Baru Algesindo

Trianto. 2007. Model-model Pembelajaran Inovatif Berorientasi Konstrutivistik. Jakarta: Prestasi Pustaka

Udin S. Winaputra. 2001. Model Pembelajaran Inovatif, Jakarta: Universitas Terbuka. Cet. Ke-1 